\title{
ANALYSIS OF THE LEVEL OF CONSCIOUSNESS RELATED TO THE OXYGEN THERAPY IN PATIENTS IN ANESTHESIA RECOVERY PERIOD
}

\author{
ANÁLISE DO ESTADO DE CONSCIÊNCIA RELACIONADO À OXIGENOTERAPIA \\ EM PACIENTES EM RECUPERAÇÃO ANESTÉSICA
}

\author{
Érica Patrícia Souza CAETANO ${ }^{1}$; Fiama Chagas NUNES²; Ana Lúcia De MATTIA ${ }^{3}$ \\ 1. Acadêmica do curso de Graduação em Enfermagem pela Universidade Federal de Minas Gerais - UFMG, Belo Horizonte, MG, \\ Brasil. ericaenf13@yahoo.com.br; 2. Enfermeira, Mestranda em Enfermagem da Escola de Enfermagem - UFMG, Belo Horizonte, MG, \\ Brasil; 3. Enfermeira, Doutora em Enfermagem, Professora Adjunta do Departamento de Enfermagem Básica, da Escola de \\ Enfermagem - UFMG, Belo Horizonte, MG, Brasil. almattia@uol.com.br \\ Apoio Financeiro da Fundação de Amparo à Pesquisa de Minas Gerais (FAPEMIG)
}

\begin{abstract}
Analyze the level of consciousness by means of the Aldrete-Kroulik scale associated with the use of oxygen therapy at the Post-Anesthesia Care Unit (PACU). It is a prospective and comparative study, with quantitative analysis. It was conducted in a big Federal Public Hospital, located in Belo Horizonte city. The sample was consisted of 60 subjects, separated between groups using and do not using oxygen therapy, aged between 18 and 64 years old, submitted to elective surgery, surgical site in upper torso, under general anesthesia, and with the American Society Anesthesiologists (ASA) status I or II. The most part of the patients were female, with 50 years old or older, classified as ASA II, under total intravenous anesthesia, and length of time of anesthesia over 240 minutes. In the analysis of the level of consciousness related to the use of oxygen therapy, it is noteworthy that the p-value $(0.069)$ is significant at the 15 minutes of permanence in the PACU. A large number of patients from the group that received supplemental oxygen therapy showed improvement in the level of consciousness at the 15 minutes of permanence in the PACU. Team work is necessary to prevent patient's complications in anesthetic recovery period.
\end{abstract}

KEYWORDS: Oxygen Inhalation Therapy. Postanesthesia Nursing. Consciousness Disorders. Anesthetics, General. Delayed Emergence from Anesthesia.

\section{INTRODUCTION}

The Post-Anesthesia Care Unit (PACU), according to the Brazilian Society of Surgical Center Nurses, Anesthesia Recovery, Sterilization and Center of Material Storage (SOBECC) is an area that provides ways to recovery after surgeries, that is, a place proposed to receive patients in the immediate postoperative period, submitted to general anesthesia and/or locoregional anesthesia, where the care are implemented until the moment that the patient be conscious, with protective reflexes and stability of vital signs (SOBECC, 2013).

The immediate postoperative period corresponds to the first 24 hours after the surgical procedure, and there are several complications that can occur in this period. These are correlated to the clinical condition of the patient in the preoperative period, type of surgery, size of surgery, and type of anesthesia (NUNES; MATOS; DE MATTIA, 2014; SILVA, 2008).

Among the various complications, we can most observe the neurological, highlighting the changes in the level of consciousness that may appear in the PACU. They are mainly due to the anesthetic agent, which can lead to the decreased level of consciousness, drowsy, amnesia, analgesia, muscle relaxation, diminished motor responses to stimuli, and reversibility (AULER JUNIOR et al., 2011).

During the interventions conducted in the PACU are necessary evaluate the mental function and level of consciousness. This important assessment is carried out using the Aldrete-Kroulik scale, which also evaluates the level of consciousness as an essential item for favorable conditions to the patient discharge from PACU (SILVA, 2008).

Evaluate the level of consciousness of the patient in the PACU corresponds to an evaluation of the functioning of the Central Nervous System (CNS), once the general anesthesia comprises a condition induced by a combination of anesthetic agents that can provide the control and reversible depression of the CNS function, which includes unconsciousness (DE MATTIA et al., 2010).

The oxygen therapy is used routinely during the immediate postoperative period, based on studies that demonstrated high prevalence of hypoxemia during this period. Other studies show that patients submitted to general anesthesia are more likely to develop postoperative hypoxemia (OLIVEIRA FILHO et al., 2001). 
Hypoxemia is defined as the reduction of the arterial oxygen content, being this the most frequent respiratory complication manifested in the PACU, which is mostly related to the anesthetics received. Commonly, the patient shows respiratory depression due to the residual action of the opioids and neuromuscular blockers, the loss of vasoconstrictor reflexes, increase of oxygen consumption, and muscle tremors (CARDOSO, 2001).

Increases in the partial pressure of carbon dioxide (PCO2), resulting from the hypoxemia can lead to depressed the level of consciousness (AULER JUNIOR et al., 2011), this portrays the importance to understand the use of oxygen therapy in the PACU as a method to prevent the increase of $\mathrm{PCO} 2$ and consequently prevent the emergence of alterations in the level of consciousness.

In order to perform preventive interventions, aimed to reduce the neurological complications associated to the hypoxemia in the postoperative period, it raises the question: Is there difference in the level of consciousness of patients who received or not oxygen therapy in the PACU?

This work was aimed to analyze the level of consciousness by means of the Aldrete-Kroulik scale associated with the use of oxygen therapy at the Post-Anesthesia Care Unit (PACU).

\section{MATERIAL AND METHODS}

It is a prospective, comparative study, with non-experimental design, and quantitative data analysis.

It was conducted at the PACU of a big public hospital in Belo Horizonte - MG. The PACU has eight beds and maintains the room temperature between $22^{\circ}$ and $24^{\circ}$ degrees Celsius, with relative humidity between $45 \%$ and $60 \%$, according to the recommendations established by Brazil's Ministry of Health.

The research project was approved by the Research Ethics Committee at Federal University of Minas Gerais (CEP UFMG), in compliance with the Resolution 466/2012 of the National Health Council, under the protocol numbers CEP UFMG 274.655 and CASE 14887213.4.0000.5149.

The subjects that composed study sample, in anesthesia recovery period, were found at the unit where they were initially admitted, by means of the daily surgical scale. The Informed Consent Form (ICF) was offered at patient's unit by the researchers, before the administration of the preanesthetic medication, when it was indicated.
The sample size was defined according to the number of predictive variables initially proposed, using between five and ten subjects for each of the variables predictive members (HO, 2006).

This study utilized six subjects for each variables, they are: age, general anesthesia, American Society Anesthesiologists (ASA) status, elective surgical procedure, and surgical site in upper torso (surgery of gastrointestinal tract, attachments organs, abdominal wall, gynecology, plastic surgery, and urology).

The sample comprised 60 subjects, divided between two groups, being 30 subjects for the group with oxygen therapy and 30 subjects for the group without oxygen therapy, admitted into the PACU, of both gender, between 18 and 64 years old, submitted to elective surgery, with surgical site in upper torso, under general anesthesia, with American Society Anesthesiologists (ASA) status I or II, and that signed the ICF.

It was excluded from the study those patients with pre-existing respiratory and neurological illnesses, ASA status III to VI, urgent and emergent surgeries, under regional anesthesia, procedures on the head and neck, upper limbs and lower limbs, and posterior portion of torso.

When the patients arrived in the PACU, considering it as minute zero (0), the subjects from the group with oxygen therapy received supplemental oxygen therapy, and the subjects from the group without oxygen therapy do not received supplemental oxygen therapy through nasal cannula. The administration or not of oxygen therapy at the PACU was a medical criteria, in this way, the researchers do not had participation in the choice of the subjects for each group, if group with oxygen therapy or group without oxygen therapy. The subjects from the group without oxygen therapy were admitted in the PACU without medical prescription for use of oxygen therapy. The removal of oxygen therapy occurred according to the criteria of nursing team, after stabilization of vital signs and the parameters of Aldrete-Kroulik scale.

For the data collection, it was elaborated a structured questionnaire, containing data relating to sociodemographic and clinical aspects of the patient, such as: gender, age, comorbidities, and ASA classification.

Data related to the anesthetic-surgical procedure were: type of maintenance of general anesthesia, if it was intravenous total or intravenous with inhalational, duration of anesthesia, and surgical specialty. 
For the analysis of the level of consciousness was applied the Aldrete-Kroulik scale during the first hour of patient's permanence at the PACU, doing it in the admission of the patient in zero (0) minutes, after 15, 30, 45 and 60 minutes.

It is importantly that in the Aldrete-Kroulik scale, the level of consciousness is one of the parameters evaluated as a criteria for the patient discharge from the PACU. According to the Aldrete-Kroulik scale, the patient receives score two (2) when lucid and oriented in time and space, score one (1) when awakens if called, and zero (0) when no answers (SOBECC, 2013).

The Aldrete-Kroulik scale evaluates jointly with the level of consciousness, the respiration, the peripheral oxygen saturation, blood circulation, and motor activity.

It selected categorical and numerical variables to be investigated. The categorical variables were: gender, ASA classification, type of anesthetic maintenance, and surgical specialty. The numerical variables were: age, duration of anesthesia, and scores corresponding to the level of consciousness according to the Aldrete-Kroulik scale.

The numerical variables were analyzed using mean and the standard deviation, Kolmogorov-Smirnov test was used to test the normality of these variables. The categorical variables were presented in a descriptive manner by absolute and relative frequencies. Proportions were compared in Tables, using the chi-square value, and p-values lower than 0.05 were considered statistically significant.

\section{RESULTS}

The results are presented addressing the sociodemographic and clinical data of the patients, and the relationship between level of consciousness and use of oxygen therapy. The sociodemographic and clinical data are presented in Table 1.

Regarding to the gender, the highest rate was for the female, in both groups. The age range was 50 years old or older, being it $16(53.3 \%)$ and $12(40.0 \%)$ for the group with oxygen therapy and group without oxygen therapy, respectively.

Relative to the ASA status classification, it had prevalence of ASA II, being 17(56.7\%) in the group with oxygen therapy and $19(63.3 \%)$ in the group without oxygen therapy.

In both groups, most part the patients had some type of comorbidity, or association of comorbidities, as Systemic Arterial Hypertension (HTN) and Diabetes Mellitus (DM), and other comorbidities, such as: obesity and renal lithiasis. These factors contributed for the most frequently of patients with ASA classification II. The frequency of comorbidities was $21(70 \%)$ in the group with oxygen therapy and $19(63.3 \%)$ in the group without oxygen therapy.

With regard to the type of anesthetic maintenance, it may be observed most frequently with intravenous anesthetic (total IV), being 22 (73.3\%) in the group with oxygen therapy and 24 $(80 \%)$ in the group without oxygen therapy.

Regarding to the length of time of anesthesia, the most part of surgeries were longer than 240 minutes, being $16(53.3 \%)$ in the group with oxygen therapy and $18(60 \%)$ in the group without oxygen therapy.

The most frequent surgical specialty was similar in both groups, procedures of digestive system, attachments organs, and abdominal wall, followed by the procedures of gynecology, according to the Table 1 .

Table 1. Frequency distribution of sociodemographic and clinical data related to use of oxygen therapy. Belo Horizonte, 2015.

\begin{tabular}{|c|c|c|c|c|c|}
\hline \multicolumn{6}{|c|}{ USE OF OXYGEN THERAPY } \\
\hline \multirow[b]{2}{*}{ Gender } & \multicolumn{2}{|c|}{ YES } & \multicolumn{2}{|c|}{ NOT } & \multirow[t]{2}{*}{ p-value } \\
\hline & $\mathbf{N}$ & $\%$ & $\mathbf{N}$ & $\%$ & \\
\hline Male & 3 & 10.0 & 9 & 30.0 & 0.053 \\
\hline Female & 27 & 90.0 & 21 & 70.0 & \\
\hline \multicolumn{6}{|c|}{ Age range (years) } \\
\hline $18-35$ & 3 & 10.0 & 7 & 23.3 & \\
\hline $36-49$ & 11 & 36.6 & 11 & 36.6 & 0.338 \\
\hline$\geq 50$ & 16 & 53.3 & 12 & 40.0 & \\
\hline
\end{tabular}

ASA 


$\begin{array}{llllll}\text { I } & 13 & 43.3 & 11 & 36.6 & 0.598 \\ \text { II } & 17 & 56.6 & 19 & 63.3 & \end{array}$

\begin{tabular}{|c|c|c|c|c|c|}
\hline \multicolumn{6}{|l|}{ Comorbidities } \\
\hline HTN & 2 & 6.6 & 2 & 6.6 & \multirow{6}{*}{0.941} \\
\hline HTN and DM & 2 & 6.6 & 2 & 6.6 & \\
\hline HTN and OTHER & 4 & 13.3 & 4 & 13.3 & \\
\hline DM and OTHER & 1 & 3.3 & 0 & 0.0 & \\
\hline OTHER & 12 & 40.0 & 11 & 36.6 & \\
\hline NONE & 9 & 30.0 & 11 & 36.6 & \\
\hline \multicolumn{6}{|l|}{$\begin{array}{l}\text { Type of anesthetic } \\
\text { maintenance }\end{array}$} \\
\hline Total IV & 22 & 73.3 & 24 & 80.0 & \multirow[b]{2}{*}{0.542} \\
\hline $\begin{array}{l}\text { Total IV and } \\
\text { inhalational }\end{array}$ & 8 & 26.6 & 6 & 20.0 & \\
\hline \multicolumn{6}{|l|}{$\begin{array}{l}\text { Duration of } \\
\text { anesthesia } \\
\text { (in minutes) }\end{array}$} \\
\hline $20-120$ & 4 & 13.3 & 6 & 20.0 & \multirow{3}{*}{0.468} \\
\hline $121-240$ & 10 & 33.3 & 6 & 20.0 & \\
\hline$>240$ & 16 & 53.3 & 18 & 60.0 & \\
\hline
\end{tabular}

\begin{tabular}{|c|c|c|c|c|c|}
\hline \multicolumn{6}{|l|}{ Surgical specialty } \\
\hline $\begin{array}{l}\text { Digestive system/ } \\
\text { attachments organs/ } \\
\text { abdominal wall }\end{array}$ & 14 & 46.6 & 12 & 40.0 & \multirow{5}{*}{0.833} \\
\hline Gynecology & 8 & 26.6 & 9 & 30.0 & \\
\hline Plastic surgery & 4 & 13.3 & 5 & 16.6 & \\
\hline Urology & 3 & 10.0 & 4 & 13.3 & \\
\hline $\begin{array}{l}\text { Urology and } \\
\text { Gynecology }\end{array}$ & 1 & 3.3 & 0 & 0.0 & \\
\hline TOTAL & 30 & 100.0 & 30 & 100.0 & \\
\hline
\end{tabular}

The Table 2, inserted below, presents the association between the level of consciousness and the use or not of the oxygen therapy in patients evaluated at the PACU, every 15 minutes, during 60 minutes, by means of the Aldrete-Kroulik scale.

It can be verified in Table 2 that there was no statistically significant difference between the use of oxygen therapy and the level of consciousness, according to the Aldrete-Kroulik scale. However, it is noteworthy that after 15 minutes the p-value is marginally significant (0.069).

It can be observed at minute zero (0), when the patients arrive in the PACU, 19 (63.3\%) of the patients of the group with oxygen therapy, got score one (1) for the level of consciousness, and in 15 minutes only $13(43.3 \%)$ presented score one (1). It demonstrates that six (6) patients reached score two (2) within 15 minutes, that is, they were awake.

It may be noted also, in the group without oxygen therapy, that $21(70.0 \%)$ of the patients who arrived at the PACU with score one (1), in 15 minutes, 20 patients were still with this score, awakening only if requested.

Upon admission in PACU, all the patients were in the same condition, that is, they were extubated in the operating room, where they were being ventilated until minutes before, and then transported to the PACU without oxygen therapy. 
Table 2. Frequency distribution of the relation between the use of oxygen therapy and level of consciousness. Belo Horizonte, 2015.

\begin{tabular}{|c|c|c|c|c|c|}
\hline \multicolumn{6}{|c|}{ USE OF OXYGEN THERAPY } \\
\hline & YES & & NOT & & p-value \\
\hline & $\mathbf{N}$ & $\%$ & $\mathbf{N}$ & $\%$ & \\
\hline \multicolumn{6}{|c|}{$\begin{array}{l}\text { Evaluation at } \\
\text { minute 0 }\end{array}$} \\
\hline 0 & 1 & 3.3 & 0 & 0.0 & \\
\hline 1 & 19 & 63.3 & 21 & 70.0 & 0.562 \\
\hline 2 & 10 & 33.3 & 9 & 30.0 & \\
\hline \multicolumn{6}{|c|}{$\begin{array}{l}\text { Evaluation at } \\
\text { minute } 15\end{array}$} \\
\hline 0 & 0 & 0.0 & 0 & 0.0 & \\
\hline 1 & 13 & 43.3 & 20 & 66.6 & 0.069 \\
\hline 2 & 17 & 56.6 & 10 & 33.3 & \\
\hline \multicolumn{6}{|c|}{$\begin{array}{l}\text { Evaluation at } \\
\text { minute } 30\end{array}$} \\
\hline 0 & 0 & 0.0 & 0 & 0.0 & \\
\hline 1 & 12 & 40.0 & 12 & 40.0 & 0.604 \\
\hline 2 & 18 & 60.0 & 18 & 60.0 & \\
\hline \multicolumn{6}{|c|}{$\begin{array}{l}\text { Evaluation at } \\
\text { minute } 45\end{array}$} \\
\hline 0 & 0 & 0.0 & 0 & 0.0 & \\
\hline 1 & 11 & 36.6 & 9 & 30.0 & 0.584 \\
\hline 2 & 19 & 63.3 & 21 & 70.0 & \\
\hline \multicolumn{6}{|c|}{$\begin{array}{l}\text { Evaluation at } \\
\text { minute } 60\end{array}$} \\
\hline 0 & 0 & 0.0 & 0 & 0.0 & \\
\hline 1 & 9 & 30.0 & 6 & 20.0 & 0.371 \\
\hline 2 & 21 & 70.0 & 24 & 80.0 & \\
\hline Total & 30 & 100.0 & 30 & 100.0 & \\
\hline
\end{tabular}

\section{DISCUSSION}

This study aimed to evaluate the level of consciousness, by means of Aldrete-Kroulik scale, associated with the use of oxygen therapy at the first hour of permanence of the patient at the PostAnesthesia Care Unit (PACU).

When the patients arrive at the PACU they may be drowsy, confused, with senses and perceptions altered, being this a result of residual effect of the anesthetics received.

Studies have shown that the prevention of hypoxemia is not the only goal, but also the oxygen therapy in the immediate postoperative can also improve the outcomes, once it reduces risks and complications (MARCONDES et al., 2006).

It is known that the level of consciousness is related to the quantitative and type of anesthetics received. The low concentration of oxygen in the body, caused by the anesthetics, can further prolong the time for the patient returns to the state of consciousness and lead to other complications (REZENDE, 2003). However, in this study, the results do not showed statistical significance between the use of oxygen therapy at the PACU and the level of consciousness, evaluated by means of the Aldrete-Kroulik scale.

The literature describes that the hypoventilation, which is the diminution of alveolar ventilation, can result in hypoxemia, reduction of oxygen concentrations in blood, or in hypercapnia, which is an excess of carbon dioxide in the blood. This condition may generate respiratory acidosis, hypoxia and apnea (AULER JUNIOR et al., 2011; BRUNNER; SMELTZER; SUDDARTH, 2012). 
The anesthetic drugs affect the CNS, but little is known about the changes in level of consciousness, because generally, they are nonselective depressants. This results in changes in sensory perception, apathy, changes in the response to stimuli, characterized by state of drowsiness and changes in the pattern of behavior, usually manifested by agitation (SILVA, 2008).

During the initial evaluation at minute zero $(0)$, which is at the moment when the patient arrives at the PACU, most the patients got score one (1), according to the Aldrete e Kroulik scale. That is, 19 $(63.3 \%)$ in the group with oxygen therapy and 21 $(70.0 \%)$ in the group without oxygen therapy. This result corroborates with the literature, when it addresses that the general anesthesia is also a predisposing factor to neurological complications, as hypoxemia (SILVA, 2008).

It can be observed that the result obtained in this study, at minute zero (0) and in 15 minutes, through the evaluation of the level of consciousness using of the Aldrete-Kroulik scale, showed greater number of patients who got score one (1), that is, when the patient wakes if requested. It confirms that the residual action of the anesthetics is present when the patient arrives at the PACU. Approximately $90 \%$ of the patients recover their consciousness after 15 minutes post admission at the PACU, otherwise, the unconsciousness is considered prolonged (AULER JUNIOR et al., 2011).

The most probable causes of hypoxemia in the postoperative period occurs due to inadequate control of ventilation or the airway permeability, resulting from the effects of residual anesthetics and/or neuromuscular blocking drugs. The most part of the hypoxic events occur during the first 15 minutes after the patient's admission in the PACU (OLIVEIRA FILHO et al., 2001; CARDOSO, 2001; POPOV; PENICHE, 2009).

The oxygen therapy in the postoperative period has shown a possible beneficial effect on arterial oxygen saturation and heart rate (KABON; KURZ, 2006), because the own impact of the anesthetic procedure on patient's pulmonary function is responsible for the hypoxemia during the immediate postoperative period (SILVA, 2008). It is known that opioids can increase the drowsiness and the need for oxygen therapy (POPOV; PENICHE, 2009). This allow us to infer that has relevance the use of oxygen therapy in the PACU, considering that in this moment, it aims the excretion the anesthetics residues in a more effective way, once patients submitted to general anesthesia are more likely to develop hypoxemia in the postoperative period (OLIVEIRA FILHO et al., 2001).
Studies confirm that in the PACU the patient is more vulnerable to have complications of the respiratory, cardiovascular, thermoregulatory, sensory, integumentary, musculoskeletal, urinary, digestive, and immune systems, besides the emotional state (NUNES; MATOS; DE MATTIA, 2014). These are physiological alterations, which basically comprise unconsciousness and cardiorespiratory depression, especially for those who receive general anesthesia (MORAES; PENICHE, 2003).

Analyzing the major complications that occur in the PACU, related to the nursing care delivered (NUNES; MATOS; DE MATTIA, 2014; SILVA, 2008), there are studies that obtained statistical significance to the use of oxygen therapy when pain, agitation/ anxiety, hypoxemia, and prevention of surgical site infection. Considering the nursing team responsibilities at the PACU, it is known that the use of oxygen therapy is one of the most important methods to prevent these several complications.

It believes that patient security at SRPA depends not only on equipment and technological resources, but also of human resources, the development of procedures and nursing interventions supported on practical and scientific knowledge. It is necessary that they are grounded in behaviors, attitudes and safe habits during their execution, thus, avoiding the occurrence of adverse events and complications, which mostly stem from the high complexity inherent in the anestheticsurgical process (SILVA, 2008).

The continuous evaluation by the nursing team in the PACU is extremely important, because the changes in the level of consciousness and in the capacity of feel and receive stimuli may interfere in the patient's ability to moving, thinking and learning. In this sense, it is up to the nurse, in their observation, identify the decreased in level of consciousness (AULER JUNIOR et al., 2011).

Studies have already shown that facing the deficit or decreased in the level of consciousness, it must be avoided the electrolyte imbalance, hyperglycemia, hypoglycemia, hypothermia, and the excess of administration of medications for neuromuscular blocking or anesthetics. This is something that in the clinical practice is divergent, mainly, because the oversupply of anesthetics and the constant need to use of reversal agents.

The team work is the main way to ensure the effective care for the patient. It is important to mention that this team is composed by anesthesiologists, nurses, nurse technicians and nurse assistants. It is responsibility of the nurses to 
provide a safe care, in a rational and individualized way, giving support for the patients during their return to normal physiological state, after the anesthesia. That instigates us for the constantly seeking for improvements and studies related to prevention of possible complications in the postoperative period. Therefore, it is essential to develop further studies related to the level of consciousness, considering the fact that the complications in the PACU are related to the preoperative clinical condition, the size and type of surgery. They must aim the establishment of measures to prevent complications and aggravations that not endanger the patient's safety and recovery during the anesthesia recovery period.

It is known that any anesthetic procedure has the potential to provoke complications. Then, in order to act preventively, it is necessary that the health team knows the possible complications and provides for the patient a continuous evaluation. It is a subject that deserves better attention, considering the many implications and/or complications that might result for the patient. Even, in nowadays, in terms of security, the risks from the anesthesia are still quite studied, as much to estimate the chance to develop complications as to achieve safe ways with better results

\section{CONCLUSIONS}

The most of the patients are female, aged with 50 years old or older, with ASA classification II, presented comorbidities, length of time of anesthesia over 240 minutes, anesthetic maintenance with total IV, and surgical specialty of digestive tract, attachments organs and abdominal wall.

There was no statistically significance among the variables researched, but we highlight a p-value marginally significant after 15 minutes of the patient's permanence in the PACU, once a number of patients from the group with oxygen therapy presented improvement in the level of consciousness.

RESUMO: Analisar o estado de consciência, através da Escala de Aldrete e Kroulik, associado ao uso da oxigenoterapia na sala de recuperação pós-anestésica (SRPA). Estudo prospectivo, comparativo, e análise quantitativa. Realizado em um Hospital Público Federal, de grande porte, na cidade de Belo Horizonte. A amostra constituída por 60 sujeitos, divididos em grupos com e sem oxigenoterapia, com idade entre 18 a 64 anos, cirurgia eletiva, acesso cirúrgico de tronco anterior, anestesia geral e classificados pela American Society of Anesthesiologists (ASA) I ou II. A maioria dos pacientes do sexo feminino, com idade maior ou igual a 50 anos, classificação de ASA II e anestesia endovenosa total, acima de 240 minutos. Na análise do nível de consciência relacionado à oxigenoterapia, ressalta-se p valor $(0,069)$, marginalmente significante aos 15 minutos de permanência na SRPA. Um número importante de pacientes do grupo que recebeu oxigenoterapia, apresentou melhora no nível de consciência, aos 15 minutos de permanência na SRPA. Ações em equipe são necessárias para prevenção das complicações do paciente em período de recuperação anestésica.

PALAVRAS-CHAVE: Oxigenoterapia. Enfermagem em pós-anestésico. Transtornos da consciência. Anestésicos Gerais. Recuperação demorada da anestesia

\section{REFERENCES}

AULER JUNIOR, J. O. C.; CARMONA, M. J. C.; TORRES, M. L. A.; RAMALHO, A. S. Anestesiologia

básica: Manual de anestesiologia, dor e terapia intensiva. 1 ed. Barueri, SP: Manole, 2011. 520 p.

BRUNNER, L. S.; SMELTZER, S. O.; SUDDARTH, D. S. Tratado de enfermagem médico-cirúrgica. 12 ed. Rio de Janeiro: Guanabara Koogan, 2012. 2404 p.

CARDOSO, A. R. Recuperação pós-anestésica. In: YAMASHITA, A. M.; TAKAOKA, F.; AULER JUNIOR, J. O. C.; IWATA, N. M. Anestesiologia SAESP. São Paulo: Atheneu, 2001. p. 1129-1141.

DE MATTIA, A. L.; FARIA, L. M.; SILVA, S. S.; OLIVEIRA, T. C. Diagnósticos de enfermería de complicaciones em la sala de recuperación anestésica. R. Electrónica Enfermería Global, v. 9, n. 18, p. 1-11, fev. 2010.

HO, R. Handbook of univariate and multivariate data analysis and interpretation with SPSS. London: Chapmam \& Hall/CRC; 2006. http://dx.doi.org/10.1201/9781420011111 
KABON, B.; KURZ, A. Optimal perioperative oxygen administration. Curr Opin Anaesthesiol., Kentucky, v.19, n.1, p. 11-18. 2006.

MACIEL, B. L. Análise da saturação periférica de oxigênio relacionada à oxigenoterapia em pacientes em período de recuperação anestésica. 2014. 15 f. Trabalho de Conclusão de Curso (Graduação em enfermagem) - Curso de Graduação em Enfermagem, Universidade Federal de Minas Gerais, Belo Horizonte, 2014.

MARCONDES, G.; SOEIRO, F. S.; FERREIRA, E. A.; UDELSMANN, A. Transporte de pacientes sem oxigenoterapia para a sala de recuperação pós-anestésica: repercussões na saturação de oxigênio e fatores de risco associados à hipoxemia. Rev Bras Anestesiol. Campinas, v. 56, n. 4, p. 352-361, Jul/ago. 2006.

MORAES, L. O.; PENICHE, A. C. G. Assistência de enfermagem no período de recuperação anestésica: revisão de literatura. Rev Esc Enferm USP. São Paulo, v. 37, n. 4, p. 34-42. 2003.

NUNES, F. C.; MATOS, S. S.; DE MATTIA, A. L. Análise das complicações em pacientes no período de recuperação anestésica. Rev SOBECC. São Paulo, v. 19, n. 3, p. 129-35, jul./set. 2014.

OLIVEIRA FILHO, G. R.; GARCIA, J. H. S.; GHELLAR, M. R.; NICOLODI, M. A.; BOSO, A. L.; MAGO, A. J. Fatores associados com a ocorrência de hipoxemia no período pós-anestésico imediato. Rev Bras Anestesiol. Florianópolis, v. 51, n. 3, p. 185-195, maio/jun. 2001.

POPOV, D. C. S.; PENICHE, A. C.G. As intervenções do enfermeiro e as complicações em sala de recuperação pós-anestésica. Rev Esc Enferm USP. Universidade São Paulo, São Paulo, v. 43, n. 4, p. 953-61, dez. 2008.

REZENDE, J. M. Apneia na sala de recuperação pós-anestésica. Relato de caso. Rev. Bras. Anestesiol. Hospital do Servidor Público Estadual de São Paulo, São Paulo, v. 53, n. 3, p. 377-381, maio/jun. 2003.

SILVA, D. C. P. Segurança do paciente no período pós-operatório imediato na sala de recuperação pósanestésica. 2008. 82 f. Dissertação (Mestrado em Enfermagem) - Curso de Pós-Graduação em Enfermagem em Saúde do Idoso, Universidade de São Paulo, São Paulo, 2008.

SOBECC, Associação Brasileira de Enfermeiros de Centro Cirúrgico, Recuperação Anestésica e Centro de Material e Esterilização. Práticas Recomendadas SOBECC. 6 ed. São Paulo: Manole, 2013. 369 p. 